\title{
The Abnormal Temperature Rises in the Lower Stratosphere After the 1982 Eruptions of the Volcano El Chichon, Mexico
}

\author{
by \\ Toshio Fujita \\ Meteorological Research Institute, Tsukuba, Ibaraki, 305 Japan
}

(Received Oct. 17, 1984 ; Revised Feb. 18, 1985)

\begin{abstract}
Abnormal temperature rises were found in the lower stratosphere over the north subtropical Pacific after the 1982 eruptions of El Chichon. The significant temperature anomalies at $30 \mathrm{mb}$ level moved westward with the El Chichon volcanic clouds.

The positive temperature anomalies from the normal were simultaneously observed with the large backscattering ratios from the lidar measurements in the southern parts of Japan.

The height-time cross section for the standardized temperature $\left(T^{\prime}=(T-\bar{T}) / \sigma_{T}\right)$ showed warming in the lower stratosphere over the eastern and central parts of the north subtropical Pacific. In the above formula $T$ is a monthly mean temperature, $\bar{T}$ is the normal and $\sigma_{T}$ is a standard deviation. The magnitudes of the anomalies were in the range between $\sigma_{T}$ and $2 \sigma_{T}$ at most in this area. On the other hand, in the western part of the north subtropical Pacific, a stratospheric warming was spectacular.

In particular, over Chichijima (about $27^{\circ} \mathrm{N}, 140^{\circ} \mathrm{E}$ ) the air layer between $30 \mathrm{mb}$ and 20 $\mathrm{mb}$ levels was abnormally warmed, with a peak anomaly of more than $5 \sigma_{T}$ at $50 \mathrm{mb}$ level in July and over $8 \sigma_{T}$ at $20 \mathrm{mb}$ level in September.

In order to investigate northward diffusion of the volcanic clouds, the height-latitude cross sections of temperature anomalies along the $140^{\circ} \mathrm{E}$ Meridian were made every month from May to December 1982.

Until June a positive temperature anomaly was limited to the south area $40^{\circ} \mathrm{N}$ lat. over Japan. But in July it diffused north of the $40^{\circ} \mathrm{N}$ circle and the time variations of the monthly maxima of the direct solar radiation in USSR showed that the volcanic clouds passed through $50^{\circ} \mathrm{N}$ latitude in October and $60^{\circ} \mathrm{N}$ in November.

Lastly it was found that the lower stratospheric temperature anomalies in the past three El Niño events did not show such remarkable warming as in 1982-83. They were all rather negative. Therefore it is not likely that the temperature rises in the lower stratosphere after the 1982 eruption of El Chichon was caused by the 1982-83 El Niño event.
\end{abstract}

\section{Introduction}

The volcano E1 Chichon $\left(17.33^{\circ} \mathrm{N}, 93.20^{\circ} \mathrm{W}\right)$ in southern Mexico violently erupted in late March and early April, 1982. (SEAN BULLETIN, Vol. 7, No. 3, 1982) The April 4 eruption was particularly strong, throwing up large quantities of volcanic ashes and sulfur- rich gases into the lower stratosphere. They were observed by the geostationary GMS, GOES satellites and the polar-orbiting NOAA7 satellite. Some of the worldwide lidars detected the stratospheric dense aerosols from the E1 Chichon eruptions.

On April 9-10, a groundbased lidar at the Mauna Loa observatory (M.L.O.), Hawaii 
$\left(19.5^{\circ} \mathrm{N}, 155.6^{\circ} \mathrm{W}\right)$, first detected several dense aerosol layers with the strongest backscattering ratio (B.S.R.) at an altitude of $25.7 \mathrm{Km}$. (SEAN BULLETIN above)

Robock (1983) made a global location map of the volcanic clouds for the first three weeks after the E1 Chichon eruptions.

The map shows that the volcanic clouds rounded the latitude zones between $10^{\circ} \mathrm{N}$ and $30^{\circ} \mathrm{N}$ for three weeks.

Labitzke et al. (1983) showed by the $30 \mathrm{mb}$ gridpoint data that the $30 \mathrm{mb}$ zonal mean temperature at $10^{\circ} \mathrm{N}$ increased in July, August, September and October, 1982, to values well above those shown for the previous 18 years. They attributed the warmer temperatures to the aerosols produced from a series of 1982 eruptions of E1 Chichon.

Parker and Brownscombe (1983) also reported a warming of the equatorial lower stratosphere after the E1 Chichon eruptions and concluded that the warming was the combined effects of the E1 Chichon eruption and the tropical stratospheric quasi-biennial oscillation (Q.B. O.).

The above two reports have it in common that the analyzed regions are restricted to relatively lower latitudes where Q.B.O. predominantly affects the stratospheric temperature anomalies.

Angell and Korshover (1983) showed that a warming of nearly $4^{\circ} \mathrm{C}$ was found at the $30 \mathrm{mb}$ level in the north subtropics two seasons after the E1 Chichon eruption.

In this paper, first, the existence of the dense volcanic aerosols in the stratosphere will be confirmed from the lidar measurements, Robock's volcanic cloud map, the direct solar radiation intensities in Japan and India, and unusual evening glows in Japan.

Next, the relationship between stratospheric dense aerosols and warmer temperature anomalies will be investigated from the lidar mesurements and aerological data in Japan.

Third, abnormal temperature rises and their northward diffusion in the lower stratosphere will be analyzed by the timeheight and latitude-height cross sections of the standardized temperature anomalies over the north subtropic Pacific and along $140^{\circ} \mathrm{E}$.

Lastly, the relationship between the remarkable E1 Niño event and stratospheric temperature anomaly will be examined.

\section{Stratospheric dense aerosols caused by the El Chichon eruption.}

The lidar measurement at M.L.O., Hawaii, first detected, on April 9, an enhancement of B.S.R. at an altitude of about $26 \mathrm{Km}$ (20 mb).

It is certain that the anomalous B.S.R. were caused by the aerosols produced from the E1 Chichon eruption on April 4, judging from the mean easterly wind velocity at the $30 \mathrm{mb}$ level over $19^{\circ} \mathrm{N}$ latitude between Mexico and Hawaii at that time. (about 12.1 $\mathrm{m} / \mathrm{sec}$ )

The global location map of the E1 Chichon clouds (Robock (1983)) showed that they moved westward through the stratospheric easterly winds. April 11 they appeared in the upper air over Wake Island $\left(19^{\circ} \mathrm{N}, 167^{\circ} \mathrm{E}\right)$ and passed through the lower stratosphere over Guam Island $\left(13^{\circ} \mathrm{N}, 145^{\circ} \mathrm{E}\right)$ on about 13 and reached the $130^{\circ} \mathrm{E}$ Meridian about next day.

In Japan, Hirono and Shibata (1983), Iwasaka et al. (1982) and Uchino et al. (1984) first observed large B.S.R. by lidar observations from late April to early May.

The turbidity coefficient at Naha $\left(26^{\circ} \mathrm{N}\right)$,

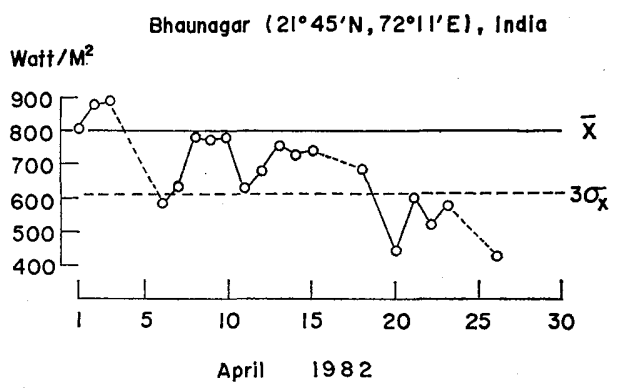

Fig. 1. Forenoon direct solar radiation during April 1982 at Bhaunagar $\left(21.75^{\circ} \mathrm{N}\right.$, $72.2^{\circ} \mathrm{E}$ ), India. $\overline{\mathrm{X}}$ and $\sigma_{\mathrm{x}}$ indicate the average and the standard deviation on the period of both April 1980 and 1981 respectively. 


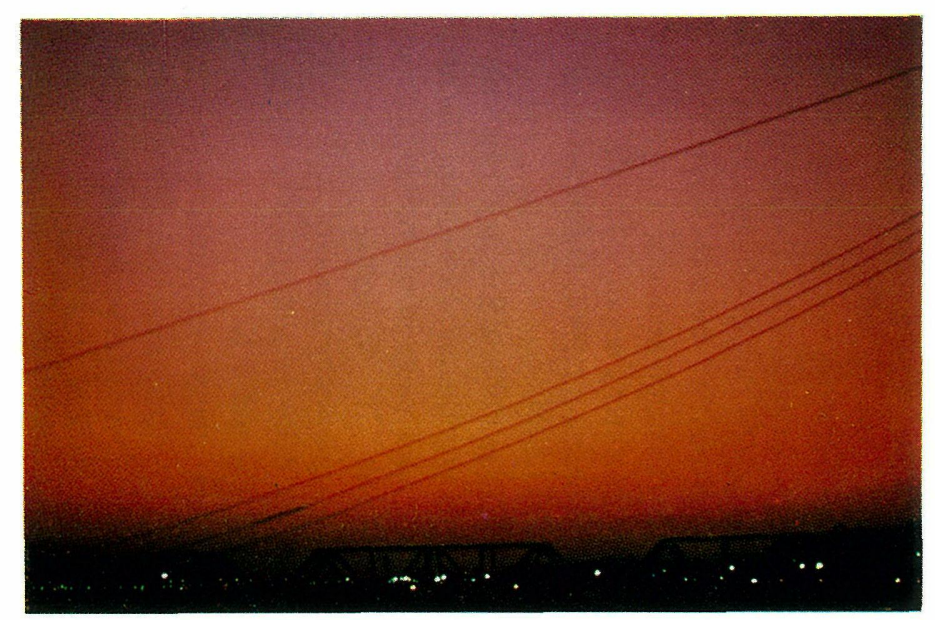

(a)

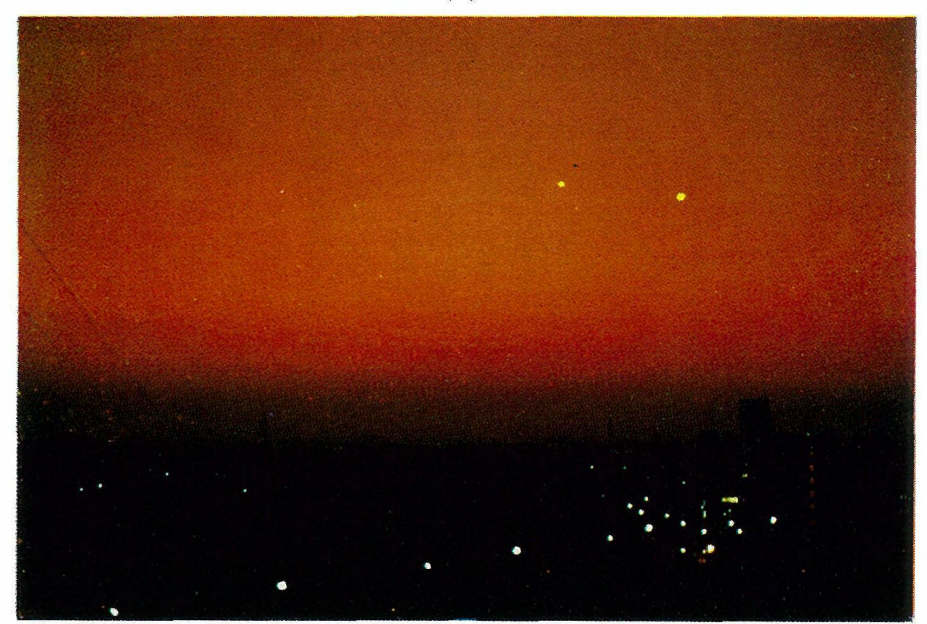

(b)

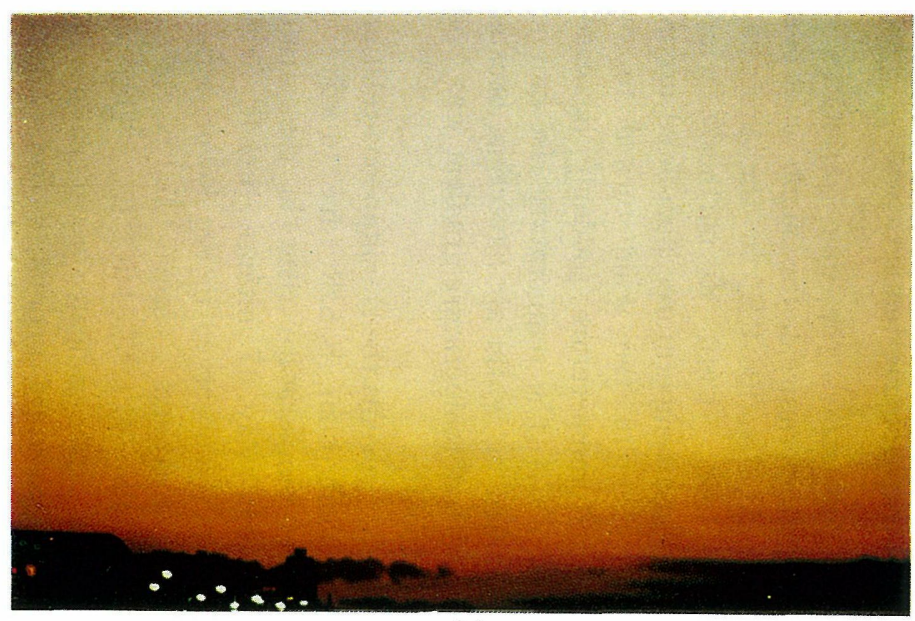

(c)

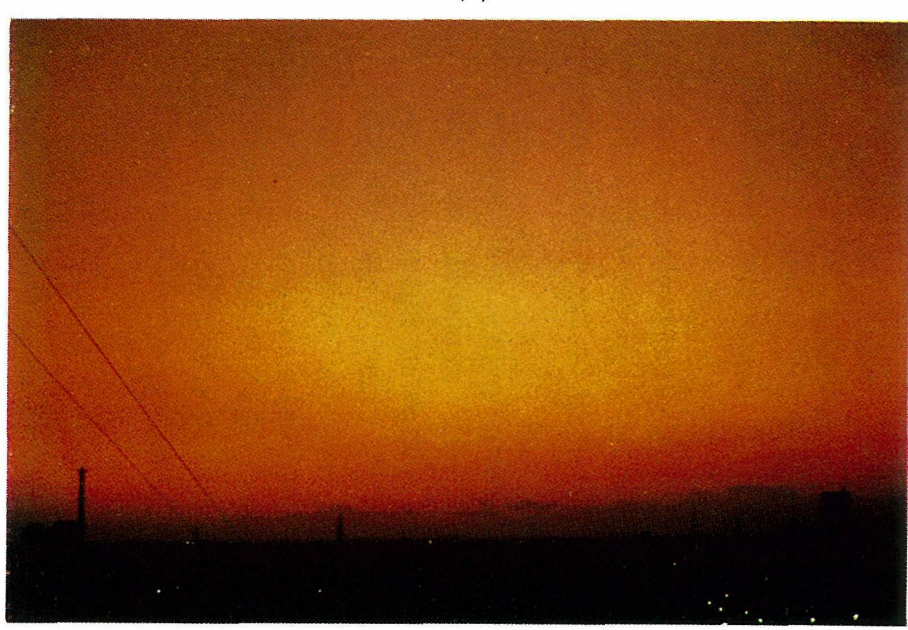

(d)

Fig. 2. Evening glows at Tsukuba and Tokyo, (a) 19: 10, May 241982 (Tokyo, solar depression angle; $-5.5^{\circ}$ ). (b) $16: 55$, Dec. 7 1982 $\left(\right.$ Tsukuba; $\left.-6.3^{\circ}\right)$. (c) $17: 25$, Jan. $151983\left(\right.$ Tokyo; $\left.-7.0^{\circ}\right)$. (d) $16: 55$, Nov. 181983 (Tsukuba; $-5.4^{\circ}$ ). 
Japan, increased in April over a standard deviation calculated from 1959 to 1983. (Yamauchi and Shimura (1984)) Also on April 20 , the direct solar radiation intensity at Bhaunagar $\left(21.75^{\circ} \mathrm{N}, 72.2^{\circ} \mathrm{E}\right)$, India, greatly decreased to below 3 times the standard deviation. (Fig. 1)

It seems that the remarkable reduction of the radiation intensity in western India corresponds to the coming of the E1 Chichon clouds on Robock's map.

Fiery red evening glows and unusual twilights which were reported by the inhabitants at many places in Japan after the middle of May 1982 also suggested the existence of dense volcanic aerosols at the lower stratosphere over Japan.

According to the SEAN BULLETIN (Vol. 7, No. 7, 1982), Lamb observed Bishop's Ring on 28 and 29 May 1982 at Norwich, England $\left(52.5^{\circ} \mathrm{N}, 1^{\circ} \mathrm{E}\right)$

Schaaf also observed a probable Bishop's Ring on 18 Feb., 1983, at Millville, New Jersey $\left(39.4^{\circ} \mathrm{N}, 74.9^{\circ} \mathrm{W}\right)$. (SEAN BULLETIN, Vol. 8, No. 2, 1983). Some of the representative evening glow photographs at Tsukuba and Tokyo are shown in Fig. 2. Evening glows in December 1982 appeared more reddish than those in late May but by mid January 1983 the red glow colors were rapidly becoming lighter. When the sun had set and its depression angle was about $-6^{\circ} \sim$ $-7^{\circ}$ (about 40 minutes after the sunset), evening glow appeared deep fiery red in the sky $2^{\circ}-3^{\circ}$ above the western horizon.

It would be suggested from simple geometry about the evening glow that the volcanic aerosols exist in the layer of about 23-25 Km. (Meinel and Meinel (1983))

The photograph shown in Fig. 2(d) was taken on Nov. 18, 1983, the evening glow being still brilliant.

Lamb (1970) defined the dust veil index, D. V.I., in which the total time between the eruption and last observation of the dust veil was used as a parameter. Therefore it is important to record how long the unusual optical phenomena continue.

\section{A relationship between volcanic debris and stratospheric temperature.}

Fig. 3(a) shows the time variations of wind and temperature at the $30 \mathrm{mb}$ level over Fukuoka $\left(33.5^{\circ} \mathrm{N}, 130.4^{\circ} \mathrm{E}\right)$ in the first half of May 1982. Until 15 northerly winds prevailed and temperatures fluctuated around $-54^{\circ} \mathrm{C}$. On 16 the wind turned to the souther and temperature suddenly increased by about $5^{\circ} \mathrm{C}$. The temperature rise can not be explained by warm air advection, because the meridional temperature gradient was from north to south.

Fig. 3(b) reveals the simultaneous relationship between lidar B.S.R. due to volcanic clouds and temperature rises in the stratosphere. On May 17 intense B.S.R. were simultaneously observed in the lower stratosphere at Fukuoka, Nagoya $\left(35.2^{\circ} \mathrm{N}, 137^{\circ} \mathrm{E}\right)$ and Tsukuba $\left(36.1^{\circ} \mathrm{N}, 140.1^{\circ} \mathrm{E}\right)$. The left side of the figure indicates a vertical profiles of the temperature anomalies from 17-year average (1964-1980), in which lateral bars mean their standard deviations.

The figures show significant temperature rises in the layer of about $3 \mathrm{Km}$ under the peak height of the B.S. R..

The simultaneous correlations between dense volcanic clouds and abnormal temperature rises in the lower stratosphere were certainly caused by aerosol absorption of visible solar radiation and long wave radiation from the warmer ocean surface (Newell (1970a, b), Robinson (1966), Ogren et al. (1981) and Hansen (1978)).

According to Pollack and Ackerman (1983), a statistically significant warming of the lower stratosphere took place in the northern tropics with the peak $\Delta T$ occurring at the $30 \mathrm{mb}$ level and having a magnitude of $3.5^{\circ} \pm 1.5^{\circ} \mathrm{K}$. Therefore a daily warming over the ocean station may exceed $6^{\circ} \mathrm{K}$.

In Fig. 4, daily temperature anomalies from the 17 years' average (1964-1980) at the $30 \mathrm{mb}$ level are presented from Hilo to Ishigakijima $\left(24.3^{\circ} \mathrm{N}, 124.2^{\circ} \mathrm{E}\right)$ on the north subtropical Pacific.

The dotted lines in the figure represent 
the standard deviation for the anomaly series on April (hereafter denoted by the symbol $\sigma$ ) and one point chain lines, the movement of

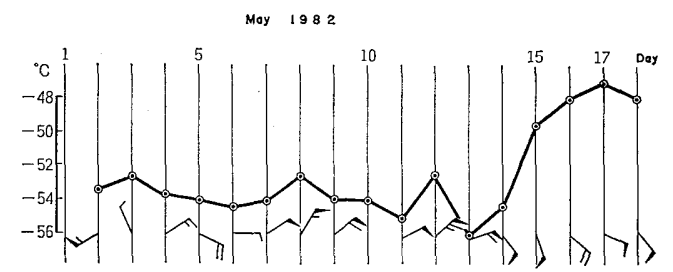

(a)

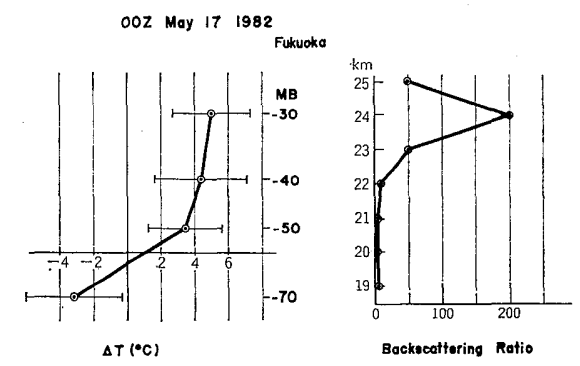

122 May $17 \quad 1982$

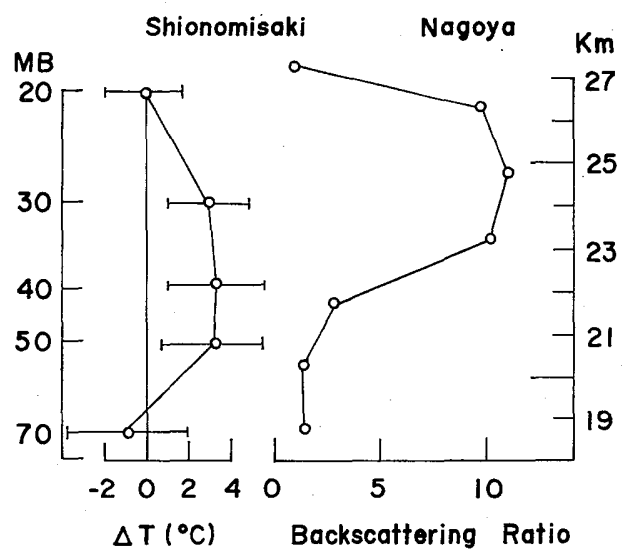

$12 Z$ May $17 \quad 1982$

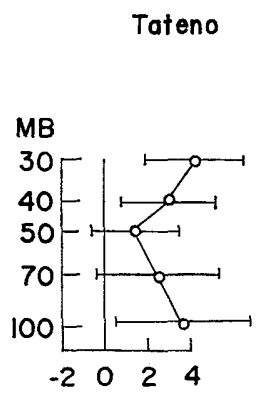

$\Delta \mathrm{T}\left({ }^{\circ} \mathrm{C}\right)$
Tateno

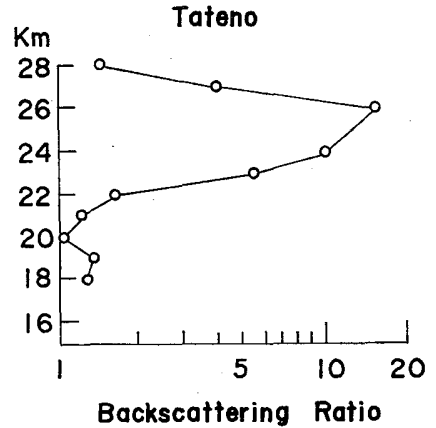

(b) the maximum temperature anomalies. Some peak positive anomalies over Hilo and Johnstone are of the order of $\sigma$ at most. In the western Pacific, however, the peak values often exceed $2 \sigma$, in particular over Marcus Island $\left(24.3^{\circ} \mathrm{N}, 154^{\circ} \mathrm{E}\right)$, on 18 remarkable warming occurred at the $30 \mathrm{mb}$ level, the temperature anomaly by $+6.6^{\circ} \mathrm{C}$ was observed, which was more than $5 \sigma$. Over Wake, Guam and Ishigakijima significant positive anomalies

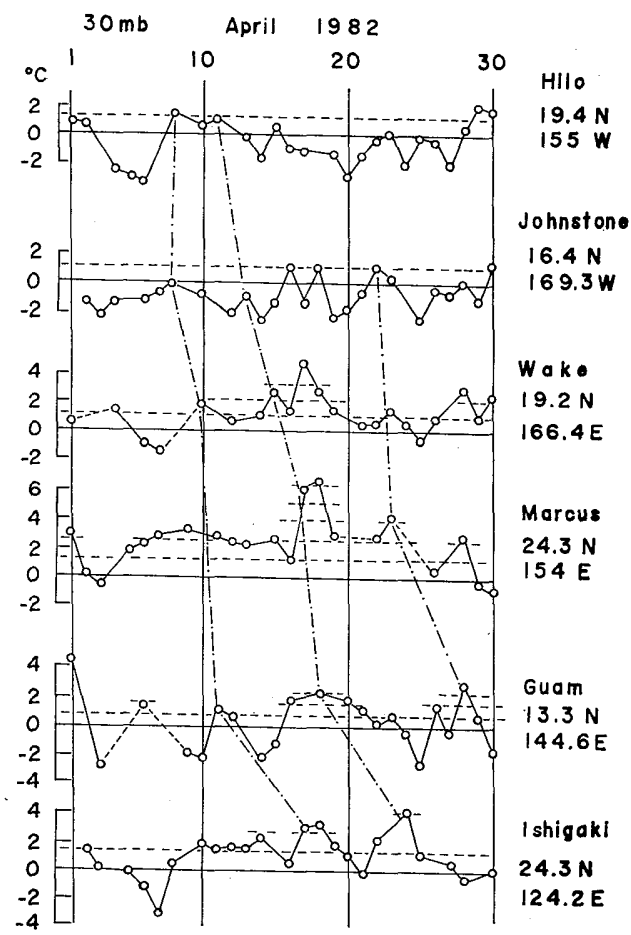

Fig. 4. Daily temperature anomaly series from 17-year average (1964-1980) at the $30 \mathrm{mb}$ level from Hilo to Ishigakijima. Dotted line indicates the standard deviation and one point chain line, the movement of a maximum anomaly.

Fig. 3. (a) A time variation of wind and temperature at the $30 \mathrm{mb}$ level over Fukuoka during the first half of May 1982. An arrow with a flag indicates a wind speed of $5 \mathrm{~m} / \mathrm{sec}$ and with a long line, $2 \mathrm{~m} / \mathrm{sec}$, with a short line, $1 \mathrm{~m} / \mathrm{sec}$ respectively.

(b) The vertical profiles of a temperature anomaly from the normal and backscattering ratio from lidar measurement which were observed May 17 at Fukuoka, Nagoya (Shionomisaki) and Tsukuba. Lateral bar means the standard deviation. 
were also observed, which exceeded $2 \sigma$ or $3 \sigma$ respectively.

An average propagation velocity of a first peak anomaly from Hilo to Ishigakijima was about $14 \mathrm{~m} / \mathrm{sec}$ and the second was about $10 \mathrm{~m} / \mathrm{sec}$.

These velocities agree relatively well with the velocity, $11.5 \mathrm{~m} / \mathrm{sec}$ which was estimated from the movement of the E1 Chichon clouds in Robock's map between 9 and 15 April.

\section{Time evolution of the abnormal temper- ature rise in the lower stratosphere.}

\subsection{Abnormal temperature rises in the lower stratosphere over the north sub- tropical Pacific.}

Volcanic clouds that travel many times around the earth would undoubtedly influence the monthly mean temperature.

In this section, the standardized temperatures, $T^{\prime}=(T-\bar{T}) / \sigma_{T}$, are analyzed, where

$T:$ monthly mean temperature

$\bar{T}$ : normal of $T$

$\sigma_{T}:$ standard deviation of $T$

The station normals and standard deviations were calculated from all available data up to 1980, that is, 30 years for Japanese stations and 17 years for the other stations. Fig. 5 shows height-time cross sections for standardized temperature anomalies at the stations in the north subtropical Pacific.

The cross sections at Hilo, Johnstone and Wake are similar to one another as shown in Fig. 5(a)-(c).

After the $\mathrm{E} 1$ Chichon eruptions, in the lower stratosphere $(30 \mathrm{mb}-50 \mathrm{mb})$, the temperature anomalies above $\sigma_{T}$ appeared in the period May 1982 to January 1983. The maximum anomaly had a magnitude over $2 \sigma_{T}$.

On the other hand, near the tropopause, a large negative anomaly was often found from July 1982 to April 1983.

In the midtroposphere the warmer anomalies with maxima $\left(2 \sigma_{T}\right.$ to $4 \sigma_{T}$ ) were found from the end of 1982 to the beginning of 1983.
The significant statistical relation between SST in the north temperate Pacific and tropospheric temperature with four seasons lag in the summer season was found by Angell (1981). Accordingly, the warmer temperature anomalies in the midtroposphere may due to the remarkable E1 Niño-like event of 1982-1983.

In Fig. 5(d)-(f) the cross sections at Marcus, Chichijima $\left(27.1^{\circ} \mathrm{N}, 142.2^{\circ} \mathrm{E}\right)$ and Minamidaitojima $\left(25.8^{\circ} \mathrm{N}, 131.2^{\circ} \mathrm{E}\right)$ are shown.

They have the common characteristics of remarkable stratospheric warming, a tropospheric cooling, with some scattared sections of warming.

They have a common feature that the maximum anomalies near the $70 \mathrm{mb}$ level in April were elevated up to the $20 \mathrm{mb}$ level from August to September and monotonously declined toward the $100 \mathrm{mb}$ level in March 1983.

Maximum anomalies had magnitudes between $2 \sigma_{T}$ and $4 \sigma_{T}$ at Marcus and Minamidaitojima; in particular at Chichijima the air layer between the $30 \mathrm{mb}$ and the $20 \mathrm{mb}$ levels was abnormally warmed up and the anomaly came up to more than $5 \sigma_{T}$ in July at the $50 \mathrm{mb}$ level, then was over $8 \sigma_{T}$ at the $20 \mathrm{mb}$ level in September.

The positive temperature anomalies near the $70 \mathrm{mb}$ level January to March 1982 may be due to what the popular press call "Mystery Clouds". The clouds were observed by the lidar measurements at Fukuoka, Hawaii and Virginia (SEAN BULLETIN, Vol. 7, No. 3).

However the B.S.R. were about $4-5$, which were less than that after E1 Chichon eruptions.

The origin of the clouds was not definitely identified but the best candidate appears to be Pagan volcano $\left(18.1^{\circ} \mathrm{N}, 145.8 \mathrm{E}\right)$, where moderate explosive activity was reported in early January (SEAN BULLETIN, Vol. 7, No. 3).

The height changes of the densest volcanic cloud are shown for every latitude from $19.5^{\circ} \mathrm{N}$ to $37^{\circ} \mathrm{N}$ in Fig. 6.

At the M.L.O. $\left(19.5^{\circ} \mathrm{N}\right)$, in early June, a 


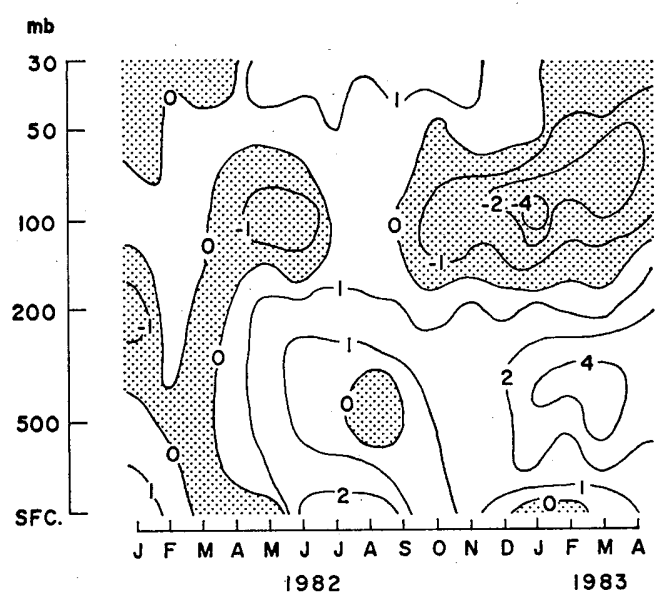

(a)

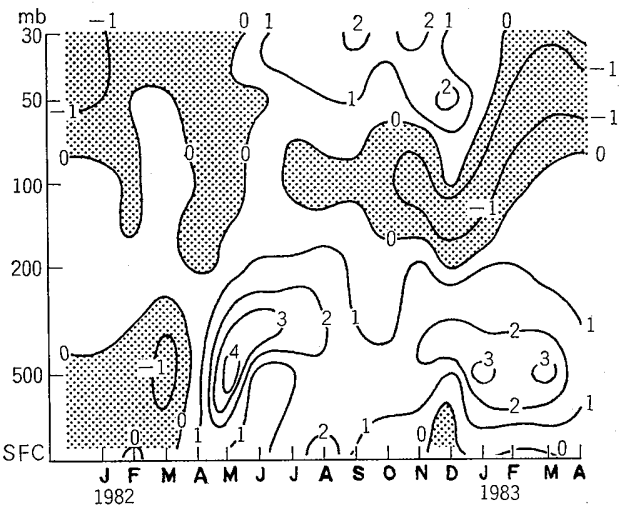

(b)

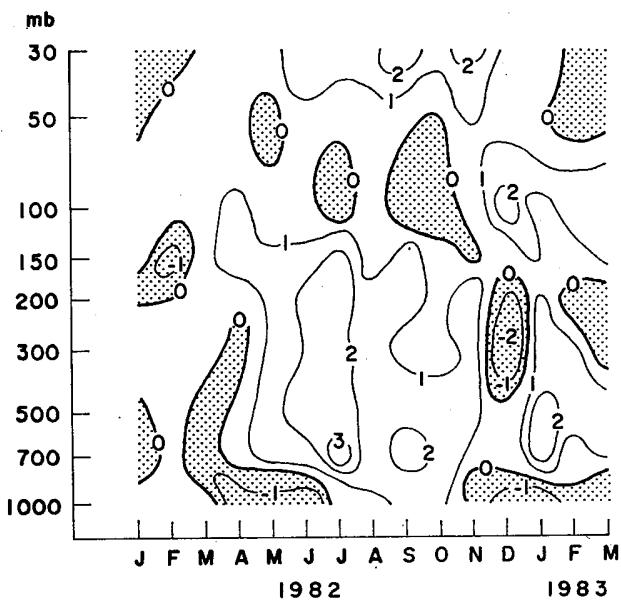

(c)
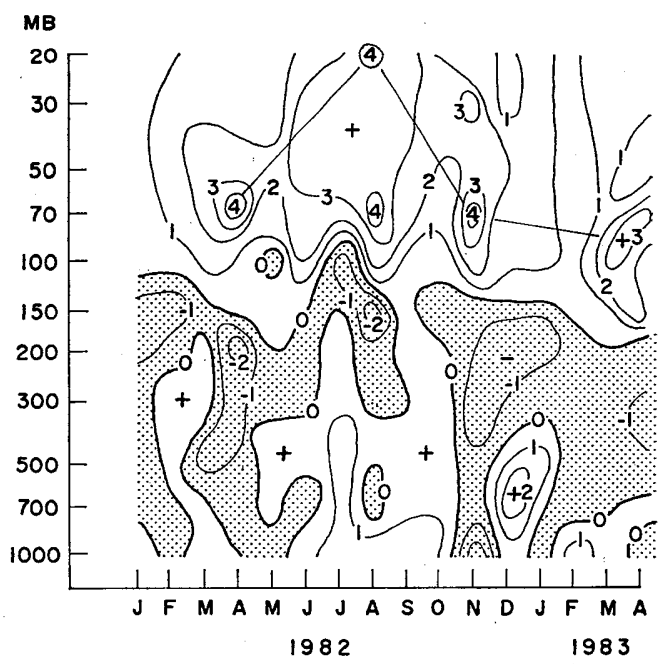

(d)

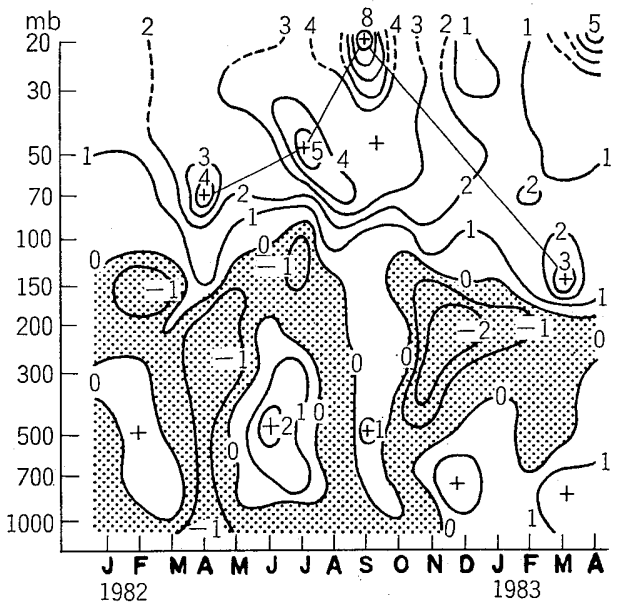

(e)

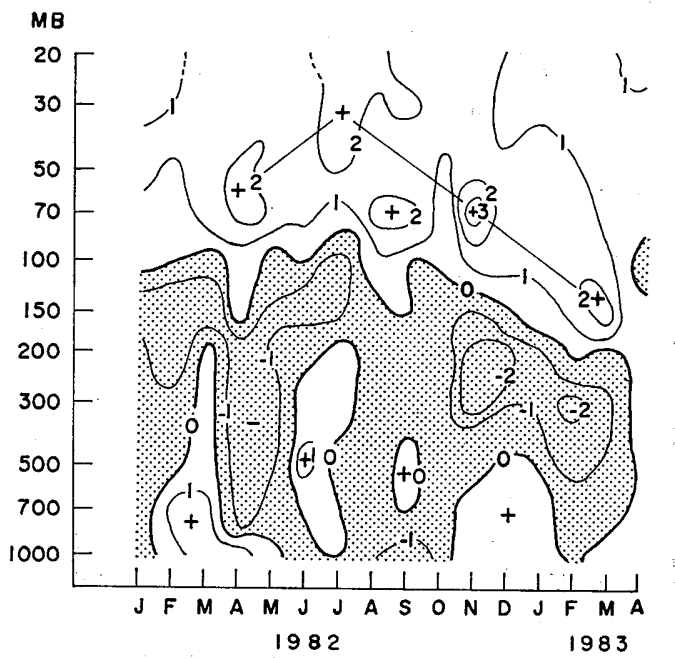

(f)

Fig. 5. (a) The height-time cross section for the standardized temperature anomaly at Hilo. (b) the same as (a) except for at Johnstone. (c) the same as (a) except for at Wake. (d) the same as (a) except for at Marcus. (e) the same as (a) except for at Chichijima. (f) the same as (a) except for at Minamidaitojima. 


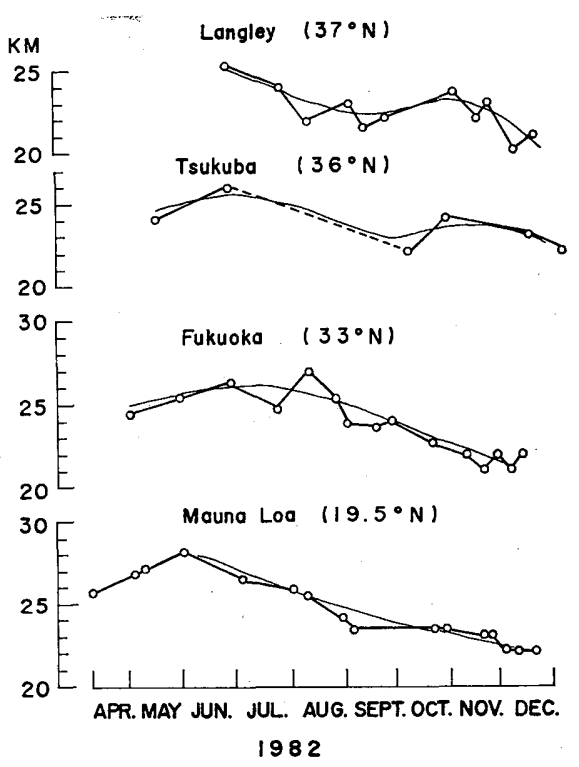

Fig. 6. The height changes of the densest volcanic clouds due to latitude from April to December 1982.

maximum B.S. R. was observed at the highest altitude $(28.2 \mathrm{Km})$ and then gradually declined until early September, after which more slowly.

At Fukuoka $\left(33^{\circ} \mathrm{N}\right)$, the aerosol-rich layer was highest in August and then linearly declined.

On the other hand, at Tsukuba $\left(36^{\circ} \mathrm{N}\right)$ and Langley $\left(37^{\circ} \mathrm{N}\right)$, a primary maximum height appeared at the end of June, declined gradually until the end of September. In early November the volcanic clouds reached a secondary maximum height.

Consequently, it is certain that the altitudes of the maximum temperature anomalies in Fig. 5(d)-(f) change in accordance with the height of the densest volcanic cloud at Fukuoka.

\subsection{Northward diffusion of stratospheric aerosols and reduction of solar radiation.}

Until August 1982 the volcanic clouds were confined to a relatively narrow range of latitudes from $0^{\circ}$ to $30^{\circ} \mathrm{N}$ (Barth et al. (1983)), while after September it seems that they abruptly began to diffuse northward as the following studies show.
According to Uchino et al. (1984), the integrated backscattering coefficients measured at Tsukuba had a large scatter till July but the scatter becames smaller and the intensities further increased in the autumn. And then they reached the maximum value in December and declined linearly with a narrow scatter from January to September 1983.

Yamauchi and Shimura (1984) made a deviation series from the 25-year (1959-1983) average of monthly turbidity factor at 14 meteorological observatories in Japan. At Naha $\left(26.2^{\circ} \mathrm{N}, 126.5^{\circ} \mathrm{E}\right)$ it increased as early as in April over a standard deviation and reached a maximum with about twice the standard deviation in June.

At Yonago $\left(35.5^{\circ} \mathrm{N}, 133.5^{\circ} \mathrm{E}\right)$, a maximum value exceeding twice the standard deviation was observed in June, temporarily declined in September, and reached a secondary maximum in December.

On the other hand, at stations north of Matsumoto $\left(36.3^{\circ} \mathrm{N}, 137.5^{\circ} \mathrm{E}\right)$, first maxima were not so obvious and were observed in late August to September, secondary peaks being also late.

Thus the results of turbidity observation in Japan well correspond to the increasing tendency of the stratospheric aerosols detected by the groundbased lidar measurements in Japan.

In order to investigate how far the north influence of stratospheric aerosols extends, the radiation data in USSR were compiled.

Fig. 7 shows a time change of direct solar radiation which is represented by a ratio to the normal (hereafter refered to simply as the ratio). The normal was calculated from the radiation data observed every 10 degrees of the latitude zone for 1969-1979.

During this period large volcanic eruptions were relatively infrequent. $8-12$ observation stations are included in every latitude zone located over the whole USSR.

Monthly maximum values of direct solar radiations were used as the radiation data. They are suitable for expressing direct solar radiation with less lower tropospheric 


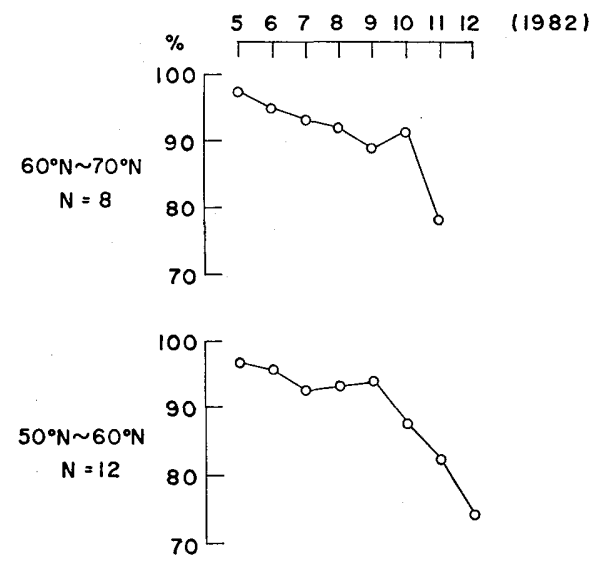

Fig. 7. Time change of the monthly maximum direct solar radiation ratio to the normal (1969-1979) in the latitude zones of $50^{\circ} \mathrm{N}-$ $60^{\circ} \mathrm{N}$ and $60^{\circ} \mathrm{N}-70^{\circ} \mathrm{N}$ in USSR. $\mathrm{N}$ is the number of the measurement station included in each zone.

aerosols.

It may be permitted to adopt a reduction of the ratio under $90 \%$ as a threshold in the abnormal reduction of solar radiation.

For, according to Kimball (1918), the three great depressions under $90 \%$ in the ratio's curve followed the great eruptions of Krakatoa in August of 1883, of Pelee, Santa Maria and Colima in 1902-1903, and of Katomai in June in 1912.

Now, as Fig. 7 shows, in the latitude zone between $50^{\circ} \mathrm{N}$ and $60^{\circ} \mathrm{N}$ (Bottom), until September the ratio kept the level of about $95 \%$ but in October it decreased under $90 \%$ and in December went down to about $74 \%$. At Vancouver, Canada $\left(49.25^{\circ} \mathrm{N}\right)$, a monthly mean aerosol optical depth began to increase sharply in October 1982 (Hay and Darby (1984)).

In the higher latitude zone between $60^{\circ} \mathrm{N}$ and $70^{\circ} \mathrm{N}$ (Top), it suddenly declined under $80 \%$ in November.

Wendler (1984) showed a figure of direct solar radiation, sky radiation and global radiation for Fairbanks, Alaska $\left(64.8^{\circ} \mathrm{N}\right.$, $\left.147.9^{\circ} \mathrm{W}\right)$. After November 15, 1982, direct solar radiation suddenly decreased by about $200 \mathrm{~W} \cdot \mathrm{m}^{-2}(24.8 \%)$, while the percentage of diffuse radiation to the global radiation abruptly increased by about $76 \%$.

He stated that the substantial disturbances. of solar radiation due to the E1 Chichon clouds began at that time.

Therefore, it may be estimated that the E1 Chichon clouds passed through $50^{\circ} \mathrm{N}$ latitude circle in October and through $60^{\circ} \mathrm{N}$ in November, and extended to the polar region at the end of 1982 .

\subsection{Height-latitude cross section of temperature anomaly.}

In order to investigate a northward movement of a warmer temperature anomaly which may be caused from the volcanic clouds, the height-latitude cross sections of temperature anomalies along the $140^{\circ} \mathrm{E}$ Meridian were made for every month.

Fig. 8(a)-(d) show them every other month from May to November 1982. The monthly mean temperatures were transformed to the standard form as mentioned earlier.

The cross section covers from $10^{\circ} \mathrm{N}$ to $45^{\circ} \mathrm{N}$ latitudes and $1000 \mathrm{mb}$ to $20 \mathrm{mb}$ levels. In May 1982, a maximum anomaly was seen at the $30 \mathrm{mb}$ level over Chichijima whose magnitude was more than $3 \sigma_{T}$ and under the maximum layer $(50 \mathrm{mb}-70 \mathrm{mb})$, a slightly warm layer $\left(1.5 \sigma_{T}>\Delta T>\sigma_{T}\right)$ extended northward over the $35^{\circ} \mathrm{N}$ latitude and above the $30 \mathrm{mb}$ level (about $24 \mathrm{Km}$ ), the anomalies were small positive or rather negative. The vertical distribution of the anomalies is well consistent with the relationship in Fig. 3(b).

A peak anomaly in May over Chichijima split into two altitudes; a warmer anomaly went down and the magnitude was more than $5 \sigma_{T}$ at the $50 \mathrm{mb}$ level, the other presented itself at the $20 \mathrm{mb}$ level whose intensity was about $4 \sigma_{T}$ in July.

On the other hand, another maximum anomaly appeared near the $30 \mathrm{mb}$ level over the $40^{\circ} \mathrm{N}$ latitude and that some warmer anomalies covered a wide section.

It is likely that the anomalies were due to the volcanic clouds, because according to Yamauchi and Shimura (1984), a monthly mean turbidity factor observed at Miyako $\left(39.6^{\circ} \mathrm{N}, 142^{\circ} \mathrm{E}\right)$ exceeded the standard devi- 


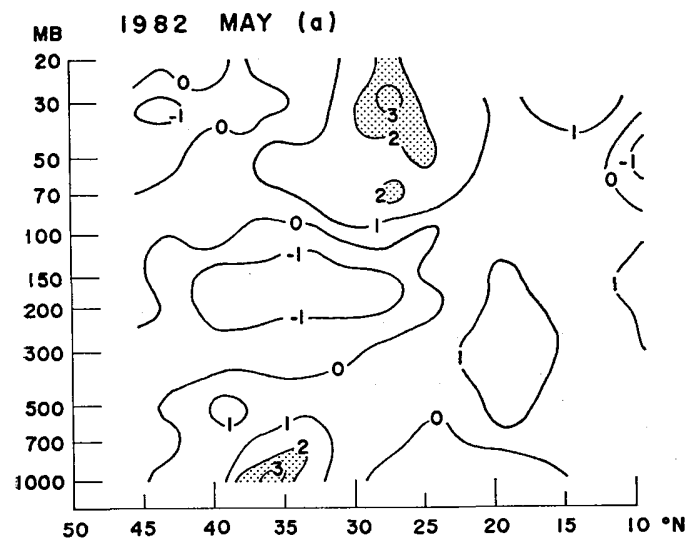

(a)

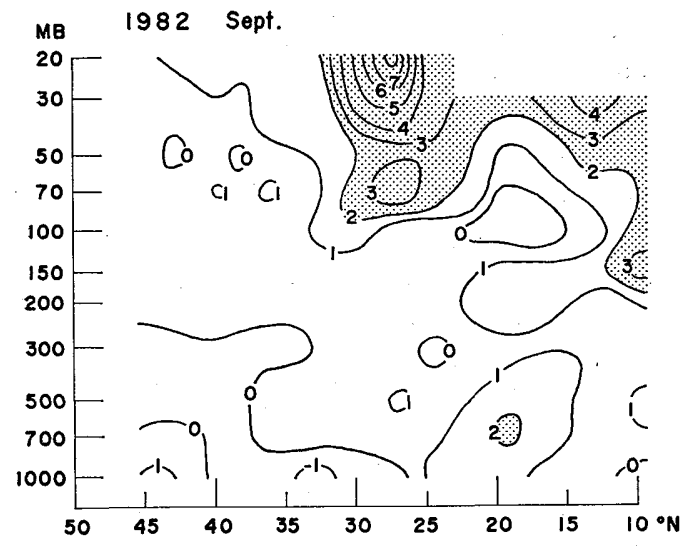

(c)

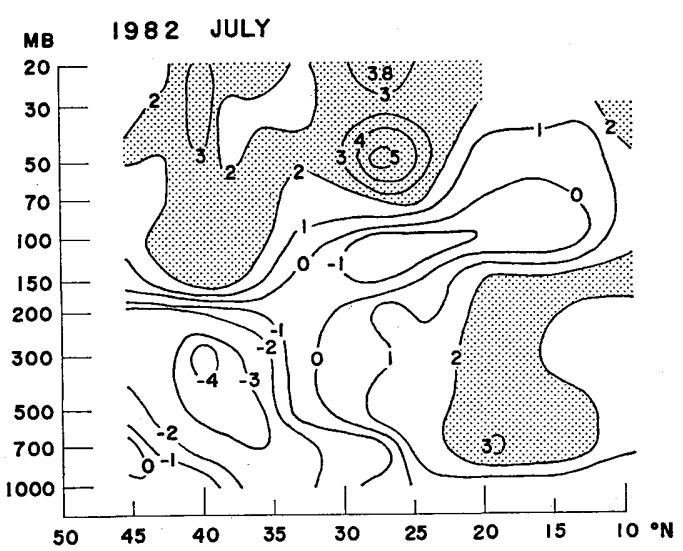

(b)

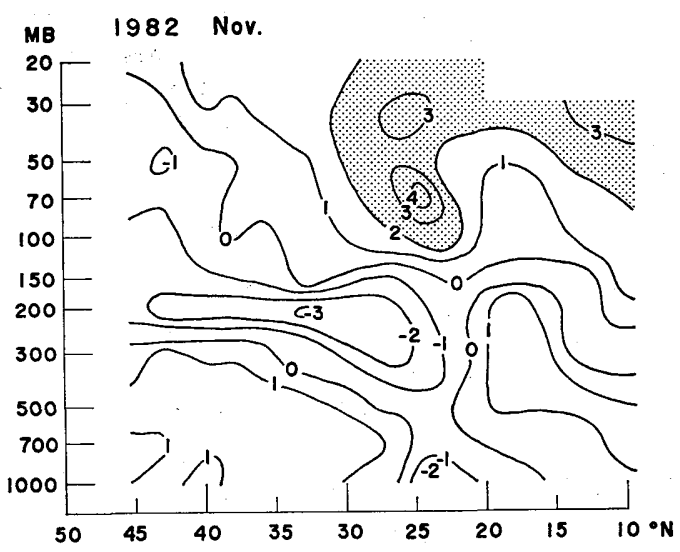

(d)

Fig. 8. (a) The height-latitude cross section for the standardized temperature anomaly along the $140^{\circ} \mathrm{E}$ Meridian in May. (b) the same as (a) except for in July. (c) the same as (a) except for in September. (d) the same as (a) except for in November.

ation. However, nothing further is known owing to a lacck of lidar observation.

It is interesting to note that the descent of an anomaly height coincides well with a height change of aerosol concentration at Fukuoka in July. (Fig. 6)

A maximum anomaly over Chichijima in July descended to the $70 \mathrm{mb}$ level in September and decreased in magnitude and the secondary maximum over $40^{\circ} \mathrm{N}$ lat. almost disappeared.

A spectacular new anomaly (over $8 \sigma_{T}$ ) was found at the $20 \mathrm{mb}$ level and some warm anomalies extended northward. This may mean that a primary maximum anomaly before August might be mainly due to fine volcanic ashes but they had settled down faster because of their large radius. After September, sulfuric acid gases from E1 Chichon were chemically converted to sulfate aerosols, which caused spectacular temperature anomalies by absorbing mainly terrestrial radiation from the warm ocean surface.

The northward extension of a warmer temperature anomaly at the $30 \mathrm{mb}$ level in September still remained in November. Judging from declining tendencies of the direct solar radiation intensities in USSR (Fig. 7) and radiation measurements at Fairbanks, the E1 Chichon clouds in the lower stratosphere would pass through $60^{\circ} \mathrm{N}$ latitude in the middle of November. 
The core of the warm temperature, however, still remained over the latitude zone between $25^{\circ} \mathrm{N}$ and $30^{\circ} \mathrm{N}$ in November. It went down from the $20 \mathrm{mb}$ level to $70 \mathrm{mb}$. It appears that the dense volcanic clouds were diffusing north and southward but the main part of them stayed at that time over the subtropical region and were actively converted into sulfate aerosols and slowly settled down (Shah and Evans (1984)).

\section{Stratospheric temperature anomalies in the El Niño events and Q. B. O. phases}

A major warm SST occurred in the
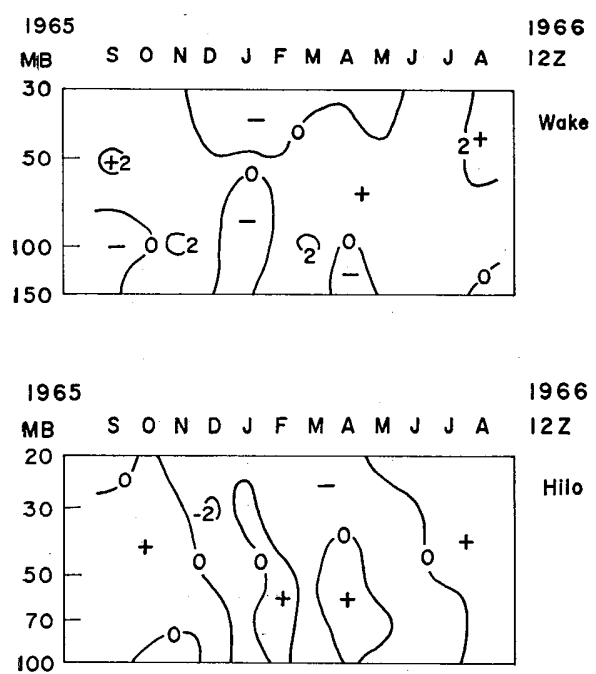

(a)
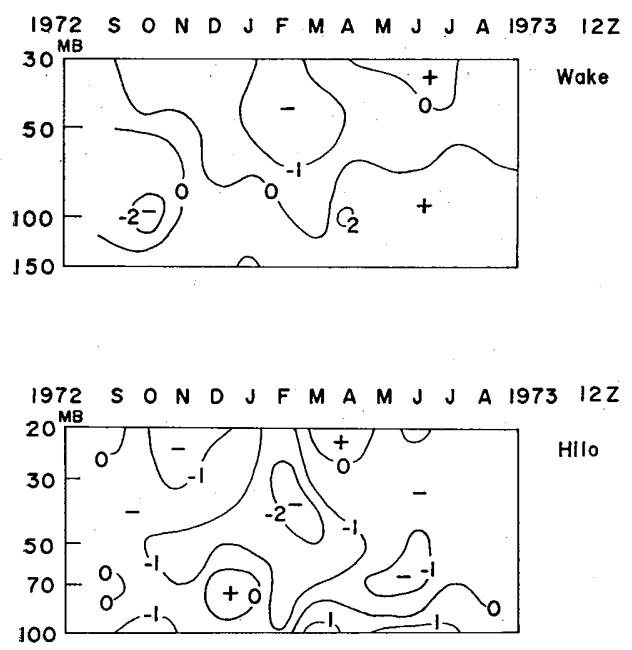

(b)
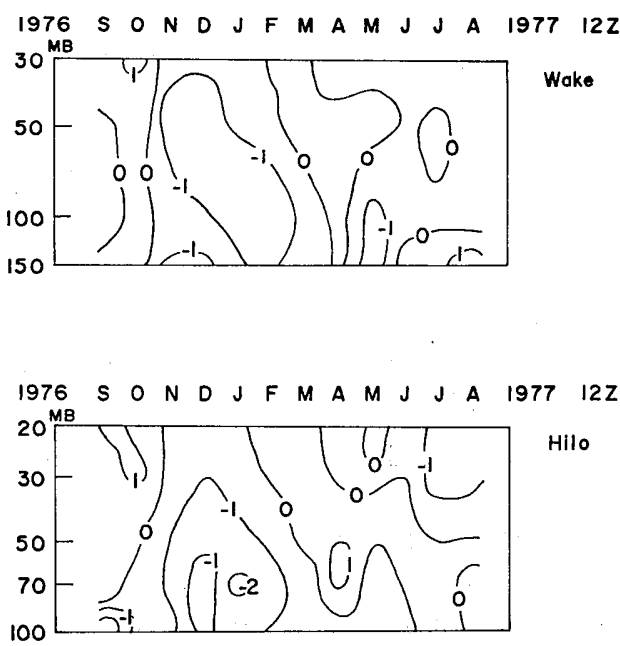

(c)

Fig. 9. (a) The height-time cross section of the standardized temperature anomaly in the lower stratosphere in 1965-66. (b) the same as (a) except for 1972 73. (c) the same as (a) except for 1976-77.

eastern and central tropical Pacific during 1982-1983. It was said that the E1 Niño was perhaps the strongest in this century.

The positive SST anomalies, however, developed during the northern summer rather than the winter which has usually been the season for this process (Parker (1983)). In addition, the 1982-1983 episode was characterized by an unusually abrupt swing of the Southern Oscillations (Rasmusson et al (1983)).

Simpson (1983) also pointed out in connection with the warming in the California Current that equatorial E1 Niño events have appeared many times in the past, only few of them seeming to have affected the California Current System strongly. And the initial collapse of the equatorial easterlies occurred in May-June rather than in OctoberNovember (Simpson (1983)).

On the other hand, the past sensitivity studies for GCM with warm SST's over different parts of the equatorial Pacific consistently indicated the negative temperature anomalies in the lower stratosphere (Chervin et al. (1980), Keshavamurty (1982) and Blackmon et al. (1983)). 
In this study the annual variations of the stratospheric temperature anomaly from 17 years average (1964-1980) at Wake and Hilo were examined in the three considerable E1 Niño events.

Fig. 9(a) shows height-time cross section of standardized temperature anomaly in the lower stratosphere, 1965-1966.

The top is a case at Wake and the bottom, at Hilo. In both figures the anomalies reveal a small value or rather a negative one. The second and the third event appeared in 1972-1973 and 1976-1977, respectively. Fig. 9(b) as well as Fig. 9(c) shows the same tendency as Fig. 9(a). In the three remarkable E1 Niño events, large positive anomalies like those in 1982-83 could not be found and in the lower stratosphere rather cool anomalies were presented in the $\mathrm{E} 1$. Niño event. It agrees with the results simulated from the GCM mentioned above.

The E1 Niño episode during 1982-83 is probably different from the past typical E1 Niño episodes in the various aspects above.

Accordingly this episode should be called an E1 Niño-like event.

Holton and Tan (1980) composited monthly mean Northern Hemisphere $50 \mathrm{mb}$ geopotential heights for a 16-year period (1962-1977) with respect to the phase of the equatorial Q.B.O. Following their Fig. 2 and Fig. 4, the difference of $50 \mathrm{mb}$ heights due to westerly and easterly categories was hardly found in the subtropical zone lower than $30^{\circ} \mathrm{N}$ lat. It means that the Q. B. O. does not affect the temperature anomalies in the lower stratosphere over the northsubtropical Pacific Ocean.

\section{Summary}

(1) It is certain from the lidar observations, direct solar radiation intensity, the global location map of the E1 Chichon clouds and the unusual evening glows, that large amounts of volcanic aerosols from the E1 Chichon eruptions existed in the lower stratosphere over Japan after May 1982.

(2) Significant temperature rises were found in the lower stratospheric layer of about $3 \mathrm{Km}$ below the height of maximum B.S.R., which were observed at Fukuoka, Nagoya and Tsukuba in the southern part of Japan. It is considered that the significant warming in the lower stratosphere resulted from absorption of solar and terrestrial radiation by the dense volcanic clouds.

(3) The results of turbidity observation in Japan correspond well to the increase of stratospheric aerosols detected from the groundbased lidar measurements. In the southern part of Japan a maximum turbidity appeared in April to May, in the central part in June to July, and in the northern part in August to September.

According to the radiation data in USSR, in the latitude zone between $50^{\circ} \mathrm{N}$ and $60^{\circ} \mathrm{N}$, the zonal mean ratio of direct solar radiation to the normal decreased to below $90 \%$ in October and in December went down to about $74 \%$. In a higher latitude zone $\left(60^{\circ} \mathrm{N}-\right.$ $70^{\circ} \mathrm{N}$ ) it suddenly decreased to below $80 \%$ in November.

(4) The height-time cross section for standardized temperatures after E1 Chichon eruptions showed a warming in the lower stratosphere over the eastern and central parts of the north subtropical Pacific. The magnitude of anomaly was in the range between $\sigma_{T}$ and $2 \sigma_{T}$ at most, where $\sigma_{T}$ indicates the standard deviation.

On the contrary, the maximum anomalies had magnitudes between $2 \sigma_{T}$ and $4 \sigma_{T}$ at Marcus Island and Minamidaitojima. In particular, over Chichijima the air layer between the $30 \mathrm{mb}$ and the $20 \mathrm{mb}$ level was abnormally warmed and the anomaly came up to more than $5 \sigma_{T}$ in July at the $50 \mathrm{mb}$ level. It was over $8 \sigma_{T}$ at the $20 \mathrm{mb}$ level in September. The altitudes of maximum warming over the western subtropical Pacific change in accordance with the height of the densest volcanic clouds at Fukuoka. (See Fig. 5(d)-(f) and Fig. 6)

In the eastern Pacific, due to major warm SST, there were so much convective clouds that volcanic clouds absorbed less terrestial radiation. 
(5) The height-latitude cross sections of temperature anomalies along $140^{\circ} \mathrm{E}$ Meridian were prepared for each month from May to November 1982. They showed that the core of warm temperature still remained over the latitude zone between $25^{\circ} \mathrm{N}$ and $30^{\circ} \mathrm{N}$ in November. The northern boundary of the warming was $35^{\circ} \mathrm{N}$ in May and then extended northward over $40^{\circ} \mathrm{N}$ in July. Jndging from the declining tendency of direct solar radiation intensities in USSR, at Vancouver and at Fairbanks, the E1 Chichon clouds in the lower stratosphere probably reached the $50^{\circ} \mathrm{N}$ lat. in October and passed through the $60^{\circ} \mathrm{N}$ lat. in the middle of November.

(6) In the three remarkable E1 Niño events in the past (1965-66, 1972-73, 1976-77), no warming could be found in the lower stratosphere over the north subtropical Pacific, where rather the cooler anomalies were prevailing. These anomalies coincide with the results simulated from GCM. Therefore it is likely that the stratospheric warming after the $1982 \mathrm{E} 1$ Chichon eruptions is not due to the 1982-83 E1 Niño-like episode. However, a significant midtropospheric warming at the beginning of 1983 over the eastern north subtropical Pacific may be due to the remarkable E1 Niño-like episode in 1982-83.

Acknowledgement:-I wish to express my hearty thanks to Mr. Taiji Yoshida, Director of the Meteorological Satellite Center, for reading the manuscript. I also thank my colleagues in the Forecast Research Division, Meteorological Research Institute, for their helpful discussions. Thanks are also extended to $\mathrm{Mr}$. N. Honda for the trouble he took in figure drawing.

\section{References}

Angell, J. K., 1981: Comparison of variations in atmospheric quantities with sea surface temperature variations in the equatorial eastern Pacific, Mon. Wea. Rev., 109, 230-243.

Angell, J. K. and J. Koshover, 1983: Comparison of stratospheric warmings following Agung and Chichon, Mon. Wea. Rev., 111, 2129-2135.

Barth, C. A., R.W. Sanders, G.E. Thomas, G. J.
Rottman, D. W. Rusch, R. J. Thomas, G.H. Mount, G. M. Lawrence, J. M. Zawodny, R. A. West and J. London, 1982: Solar mesosphere explorer measurements of the El Chichon volcanic cloud, Bull. Amer. Met. Soc. 63, 1314.

Blackmon, M.L., J.E. Geisler and E. J. Pitcher, 1983: A general circulation model study of January climate anomaly pattern associated with interannual variation of equatorial Pacific sea surface temperature, Jour. Atmos. Sci., 40, 1410-1425.

Chervin, R. M., J.E. Kutzbach, D. D. Houghton and R. G. Gallimore, 1980: Response of the NCAR general circulation model to prescribed changes in ocean surface temperature. Part II : Midlatitude and Subtropical changes, Jour. Atmos. Sci., 37, 308-332.

Hansen, J.E., Wei-Chyung Wang and A. A. Lacis, 1978: Mount Agung eruption provides test of a global climatic perturbation, Science, 199, 1065-1067.

Hay, E. and R. Darby, 1984: El Chichon-Influence on aerosol optical depth and direct, diffuse and total solar irradiances at Vancouver, B.C., Atmo.-Ocean, 22, 354-368.

Hirono, M. and T. Shibata, 1983: Enormous increase of stratospheric aerosols over FUKUOKA due to volcanic eruption of El Chichon in 1982, Geophys. Res. Lett., 10, 152-154.

Holton, J. R. and H-C. Tan, 1980: The influence of the equatorial quasi-biennial oscillation on the global circulation at $50 \mathrm{mb}$, Jour. Atmos. Sci., 37, 2200-2208.

Iwasaka, Y., S. Hayashida and A. Ono, 1982 : Laser radar measurements of the stratospheric aerosol (I) January-October 1982: NAGOYA, JAPAN, WRI MAP Research Note, 1, 1-15.

Keshavamurty, R. N., 1982: Response of atmosphere to sea surface temperature anomalies over the equatorial Pacific and the teleconnections of the Southern Oscillation, Jour. Atmos. Sci., 39, 1241-1259.

Kimball, H. H., 1918: Volcanic eruptions and solar radiation intensities, Mon. Wea. Rev. 46, 355356.

Labitzke, K., B. Naujokat and M.P. McCormik, 1983: Temperature effects on the stratosphere of the April 4, 1982 eruption of El Chichon, Mexico, Geophys. Res. Lett., 10, 24-26.

Lamb, H. H., 1970: Volcanic dust in the atmosphere. Phil. Trans. Roy. Soc., A-266, 426-533.

Meinel, A. and M. Meinel, 1983: Sunsets, twilights and evening skies, pp. 163, Cambridge Univ. Press, Cambridge.

Newell, R.E., 1970a : Modification of stratospheric properties by trace constituents changes, Nature, 227, 697-698.

Newell, R.E., 1970b: Stratospheric temperature 
change from the Mt. Agung volcanic eruption of 1963, Jour. Atmos. Sci., 27, 977-978.

Ogren, J. A., R. J. Charlson, L.F. Radke and S. K. Domonkos, 1981: Absorption of visible radiation by aerosols in the volcanic plume of Mount St. Helens, Science, 211, 834-835.

Parker, D. E., 1983: Documentation of a Southern Oscillation Index., Met. Mag., 112, 184-188.

Parker, D.E. and J. L. Brownscombe, 1983: Stratospheric warming following the El Chichon volcanic eruption, Nature, 301, 406-408.

Pollack, J.B. and T.P. Ackerman, 1983: Possible effects of the $\mathrm{El}$ Chichon volcanic cloud on the radiation budget of the north tropics, Geophys. Res. Lett., 10, 1057-1060.

Rasmusson, E.M. and J.M. Wallace, 1983: Meteorological aspects of the El Niño/Southern Oscillation, Science, 222, 1195-1202.

Robinson, G. D., 1966: Some determinations of atmospheric absorption by measurement of solar radiation, Quart. J. Roy. Meteor. Soc., 92, 263-269.

Robock, A., 1983: El Chichon provides test of volcanoe's influence on climate, National Weather Digest, 8, 40-45.

Shah, G. M. and W.F. J. Evans, 1984: Aircraft latitude survey measurements of the $\mathrm{El} \mathrm{Chi-}$ chon eruption cloud., Geophy. Res. Lett., 11, 1125-1128.

Simpson, J. J., 1983 : Large-scale thermal anomalies in the California current during the 1982-1983 El Niño, Geophys. Res. Lett., 10, 937-940.

Uchino, O., K. Takahashi, I. Tabata, I. Akita, Y. Okada and K. Naito, 1984: Ruby lidar observations of the $\mathrm{El}$ Chichon dust clouds at Tsukuba $\left(36.1^{\circ} \mathrm{N}\right)$ and comparisons with UV lidar measurements at Fukuoka $\left(33.6^{\circ} \mathrm{N}\right)$, J. Met. Soc. Japan, 62, 679-687.

Yamauchi, T. and H. Shimura, 1984: The effect of El Chichon eruption in 1982 on the atmospheric turbidity, (in Japanese), Tenki, 31, 533-544.

Wendler, G., 1984: Effects of the El Chichon volcanic cloud on solar radiation received at Fairbanks, Alaska, Bull. Ameri. Meteor. Soc., $65,216-218$.

\title{
1982年エル・チチヨン火山の爆発後の下部成層圈異常昇温
}

\author{
藤 田敏 夫
}

1982年のエル・チチョン火山の爆発のあとで北太平洋の亜熱帯の下部成層圈で異常昇温がみらられた。 $30 \mathrm{mb}$ 面の 高温偏差はェル・チチヨンの火山雲とともに西方に流された。平年値からの有意な高温偏差がライダー観測による 強い後方散乱比と同時に日本南部の各地で観測された。基準化された温度偏差 $\left(T^{\prime}=(T-\bar{T}) / \sigma_{T}\right)$ の高度一時間 断面図には北太平洋の覀熱帯の東部扣よび中部上空で $\sigma_{T} \sim 2 \sigma_{T}$ の範囲の昇温が示された。一方，西部业熱帯上空 での昇温は驚くべきものであった。とくに，父島上空の $30 \mathrm{mb} 20 \mathrm{mb}$ の間の気層は異常に暖められ，その最大值 は7月の $50 \mathrm{mb}$ 面で $5 \sigma_{T}$ 以上, 9 月には $20 \mathrm{mb}$ 面で $8 \sigma_{T}$ にも達した。火山雲の北方への移動を調べるために, $140^{\circ} \mathrm{E}$ 子后面に沿って平年值（1964-1982年）からの気温偏差の高度緯度断面が 5 月から12月まで毎月作られた。

6 月までは，高温偏差域は日本の上では $40^{\circ} \mathrm{N}$ 以南の地域に限られていたが， 7 月には $40^{\circ} \mathrm{N}$ 圏をこえて北へ拡 がり，ソ連邦の直達日射量の月最大值の時間変化によると火山雲は 10 月には $50^{\circ} \mathrm{N}$ をこえ，さらに 11 月には $60^{\circ} \mathrm{N}$ を通過したことが分った。

最後に, 過去 3 回の顕著なエル・ニーニョ現象のときの下部成層圈気温の偏差はいつれれる 1982-1983年のような 著るしい昇温は示さず，むしろ負の偏差であった。従って 1982 年のエル・チチョン爆発後の下部成層圏の昇温は 1982-1983年のエル・ニーニョ現象が原因ではなかったと思われる。 